\title{
CHARACTERIZATION OF THE INTERNAL REPRODUCTIVE ORGANS AND THEIR STATE AS DIAPAUSE INDICATOR IN Phytalus sanctipauli BLANCHARD, 1850 (COLEOPTERA, SCARABAEIDAE)
}

\author{
LÚCIA M. GUEDES DIEFENBACH, LUIZA RODRIGUES REDAELLI’ and \\ DIRCEU NERI GASSEN" \\ Departamento de Fitossanidade, Faculdade de Agronomia, UFRGS, Av. Bento Gonçalves, 7712, \\ CEP 91501-970, Porto Alegre, RS, Brazil \\ "EMBRAPA - Trigo, C.P. 569, CEP 99001-970, Passo Fundo, RS, Brazil \\ Correspondence to: Lúcia M. G. Diefenbach, Departamento de Fitossanidade, Faculdade de Agronomia, \\ UFRGS, Av. Bento Gonçalves, 7712, CEP 91501-970, Porto Alegre, RS, Brazil \\ Received July 07, 1997 - Accepted June 05, 1998 - Distributed August 28, 1998
}

(With 6 figures)

\begin{abstract}
The internal reproductive organs of females and males of Phytalus sanctipauli are described and illustrated. The amount of fat body in the abdominal cavity was assessed. The remaining in the soil, from March to September, of sexually immature females and males bearing the abdominal cavity totally filled with fat body characterized the state of diapause in this species, in Coxilha $\left(52^{\circ} 20^{\prime} \mathrm{W}\right.$ and $28^{\circ} 05^{\prime}$ S), RS, Brazil.
\end{abstract}

Key words: Phytalus sanctipauli, wheat white grub, diapause, internal reproductive organs, fat body.

\section{RESUMO}

\section{Caracterização dos Órgãos Internos de Reprodução e Respectivas Mudanças como Indicadores da Diapausa em Phytalus sanctipauli Blanchard, 1850 (Coleoptera, Scarabaeidae)}

Os órgãos internos de reprodução de fêmeas e machos de Phytalus sanctipauli são descritos e ilustrados e a quantidade de corpos gordurosos presentes na cavidade abdominal é avaliada. A permanência no solo de fêmeas e machos, sexualmente imaturos e com a cavidade abdominal totalmente preenchida com corpos gordurosos, no período de março a setembro, em Coxilha $\left(52^{\circ} 20^{\prime} \mathrm{O}\right.$ e $\left.28^{\circ} 05^{\prime} \mathrm{S}\right)$, RS, Brasil, caracterizaram o estado de diapausa imaginal desta espécie.

Palavras-chave: Phytalus sanctipauli, coró do trigo, diapausa, órgãos internos de reprodução, corpos gordurosos.

\section{INTRODUCTION}

One of the most frequently cited species of scarab beetle associated with winter cereals is Phytalus sanctipauli Blanchard, 1850. Its larvae represent an important soil dwelling pest in the central high plain of Rio Grande do Sul, Southern Brazil, where it may cause severe though often localized damage to wheat, oat, barley and even maize when sowed early. The larvae may attack the plants soon after emergence and eat both roots and seeds resulting in the reduction of the plant stand (Gassen, 1993).

In spite of its economic importance, information about the life cycle of this species is scarce. Diefenbach et al. (1996) recorded a two year life cycle to this species in Southern Brazil. The adults emerge in March, remain in the soil about 7 months and then come to the soil surface and engage in mating activities.

Among the life history strategies of insects, dormancy is an important adaptation that en- 
hances survival levels through unfavourable periods and promotes synchronization of the life cycle with seasonal changes in the environment (Tauber et al., 1986).

Fujiyama (1983) already pointed out the importance of diapause in synchronizing the life cycle in Scarabaeidae. Many authors previously observed the imaginal diapause in different species of this family. In Minnesota (USA), Sweetman (1931) recorded it for Phyllophaga anxia, $P$. implicita, P. fusca and P. drake); Richter (1940), in Kentucky (USA), for $P$. hirticula, $P$. rugosa, $P$. fusca and P. crenulata, Guppy \& Harcourt (1970), in Quebec (Canada), for P. fusca; Berberet \& Helms (1972), in Nebraska (USA), for P. anxia.

Insects which go through diapause as imagos may show, among other physiological changes, accumulation of reserve substances as hypertrophied fat body and arrestment in the development of the reproductive organs (Lees, 1955, Beck, 1980; Tauber et al. 1986). Thus, both aspects may be used for the characterization of diapause and, in this way, may be an important tool for interpretation of field population data and subsidies to integrated pest management.

Therefore, this paper aims to describe the internal reproductive organs of $P$. sanctipauli and to assess the developmental conditions of these organs and also the amount of fat body contained in the abdominal cavity of individuals from March to October as a basis for characterization of the diapause state.

\section{METHODS AND MATERIALS}

Adults of $P$. sanctipauli were sampled in the soil, under a commercial black oat/soybean rotational crop at Coxilha County, RS $\left(52^{\circ} 20^{\prime} \mathrm{W}\right.$ and $28^{\circ} 05^{\prime} \mathrm{S}$ ), from March to October 1995 and thereafter in 10 pitfall traps until December. Sampling was conducted in an area of approximately $150 \times 70 \mathrm{~m}$ amidst the crop, previously chosen because it was heavily infested by third instar grubs of $P$. sanctipauli. A regular sampling program was planned so that 20 sampling units were taken per sampling occasion at approximately two weeks intervals. In those occasions 2 plant rows were randomly chosen and samples were taken by digging rectangular holes of $20 \times 50$ (sides) x 35 $\mathrm{cm}$ (depth) at each 2 meters along the plant rows. The soil extracted was carefully examined. All specimens collected were transferred to 7.51 plastic buckets containing soil and taken to the laboratory where they was stored at $6^{\circ} \mathrm{C}$ until dissection occurred. For each sampling occasion, about 3 males and 3 females were dissected. A total of 57 females and 40 males were dissected and observed. Freshly killed specimens, with fumes of ethyl ether, were dissected in $70 \%$ ethyl alcohol and examined under a Wild M5 stereomicroscope. Illustrations of the internal reproductive organs were made with the aid of a camera lucida and the developmental condition (immature, mature, post-reproductive for females and immature and mature, for males) was also assessed. The internal organs were removed from the abdominal cavity and distended and positioned in the dissection dish in order to allow an adequate visualization of the structures. The amount of fat body present in the abdominal cavity was qualitatively evaluated. Measurements of the width and length of the bursa copulatrix and the major axis of three follicles in each testis were taken from 42 females and 33 males respectively.

\section{RESULTS AND DISCUSSION}

The female reproductive organs (Figs. 1, 2 and 3)

There are 6 ovarioles $(\mathrm{Ov})$ per ovary $(\mathrm{O})$, which is the basic number found in Scarabaeidae (Robertson, 1961; Crowson, 1981). The ovarioles are of the meroistic telotrophic type (Chapman, 1985). There is a terminal filament at the apex of each ovariole which join and form a single suspensory ligament (SL) per ovary, both suspensory ligaments join originating a median ligament in a way that the two ovaries are fixed in a common point in the body wall. Each ovariole opens through a pedicel in the calix of its respective lateral oviduct (LO), the latter being very short relative to the system as a whole. The common oviduct (CO) is also short. The vagina expands laterally forming an elongate bursa copulatrix (BC). Both the spermathecal (S) capsule and its gland (SG) have a club like shape. The spermatheca opens by a short duct (SD) dorsally in the common oviduct-vagina junction distally relative to the bursa. In situ, in dorsal view the spermathecal apparatus and the bursa copulatrix lie in the right side of the abdominal cavity.

Similar characteristics in the female internal reproductive organs are reported for other 
scarabs species: Phyllophaga sp. (Williams, 1945); Aphodius tasmaniae (Hope) (Maelzer, 1961); Costelytra zealandica (White) (Fenemore, 1971); Phyllophaga anxia (LeConte), (Berberet \& Helms, 1972); Heteronychus arator (Fabricius) (Mercer \& King, 1976), and Odontria striata White (Barratt \& Campbell, 1982).

The reproductive organs of an immature female (Fig. 1) are frail and occupy a small portion of the abdominal cavity, which is almost totally filled up by fat body. The ovarioles are small, coalescent and wrapped in tracheoles. The vitelarium, lateral oviducts, and the common oviduct are milky white and translucent. The germarium can not be distinguished from the vitelarium. There are no developing oocytes in the vitelarium or eggs in the lateral oviducts. The bursa copulatrix has a creamy white color and measures in average $2.31 \pm 0.056 \mathrm{~mm}$ in length and $0.82 \pm$ $0.028 \mathrm{~mm}$ in width. The spermathecal gland and capsule are white and translucent.

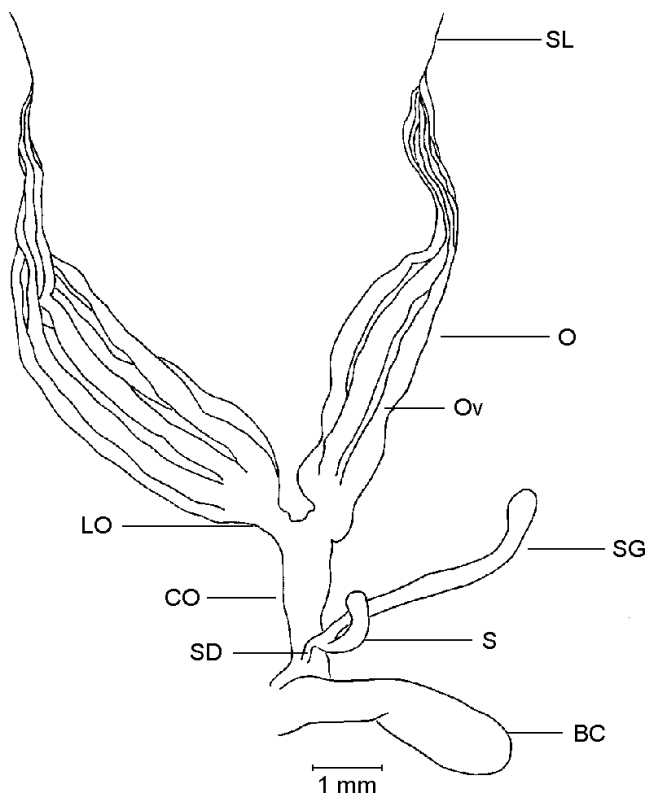

Fig. 1 - Female internal reproductive organs of a sexually immature specimen of Phytalus sanctipauli Blanchard, dorsal view. $\mathrm{BC}$ - bursa copulatrix; $\mathrm{CO}$ - common oviduct; $\mathrm{LO}$ lateral oviduct; O - ovary; Ov - ovariole; $\mathrm{S}$ - spermatheca; SD - spermathecal duct; SG spermathecal gland; SL - suspensory ligament.

The reproductive organs of a fully mature female (Fig. 2) are greatly increased in volume (approximately 5 times relative to an immature female), filling up most of the abdominal cavity.
The ovarioles exhibit a noteworthy increase mainly in diameter when compared to those of an immature female. Oocytes (Oo) in different stages of development are present in the vitelarium. The fully developed corionated oocyte is creamy white and shiny. In general, the greatly distended lateral oviducts harbour at most 5 to 6 mature oocytes. After copulation the bursa copulatrix becomes dilated and shows a dark brownish color The bursa copulatrix measures in average $2.50 \pm$ $0.080 \mathrm{~mm}$ in lenght (significantly larger than in the immature; $\mathrm{t}=2.02 ; \mathrm{df}=53 ; \mathrm{P}<0.05)$ and $0.85 \pm 0.040 \mathrm{~mm}$ in width not significantly wider than in the immature $(\mathrm{t}=0.54 ; \mathrm{df}=53, \mathrm{P}>0.05)$. The spermathecal gland and capsule are white and translucent.

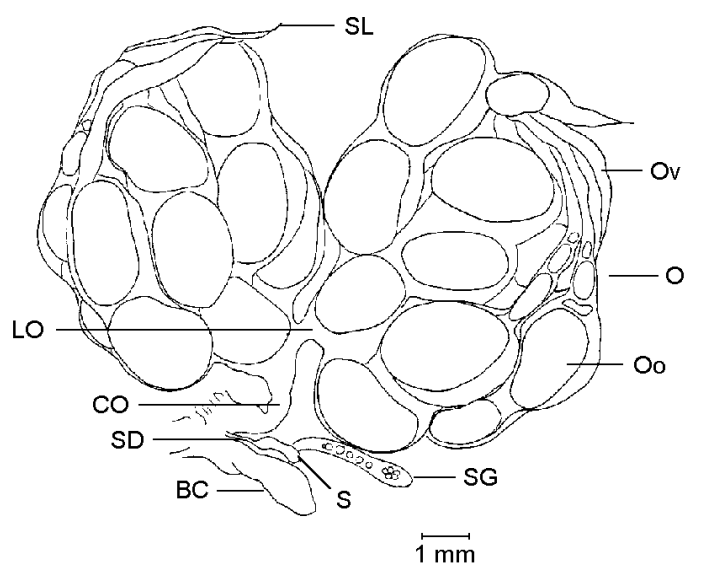

Fig. 2 - Female internal reproductive organs of a sexually mature specimen of Phytalus sanctipauli Blanchard, dorsal view. BC - bursa copulatrix; $\mathrm{CO}$ - common oviduct; $\mathrm{LO}$ lateral oviduct; O - ovary; Ov - ovariole; Oo - oocyte; S spermatheca; SD - spermathecal duct; SG - spermathecal gland; SL - suspensory ligament.

In the post-reproductive female the organs are similar in size to those of an immature female but have a worn aspect. The bursa copulatrix retains a brown color and both the spermathecal capsule and gland have a collapsed aspect (Fig. 3). The corpora lutea (CL) are present but very faint.

\section{The male reproductive organs (Figs. 4 and 5)}

There is a pair of testes ( $\mathrm{T})$ situated laterally relative to the alimentary tract. Each testis consists of 6 globular follicles $(\mathrm{F})$, individually connected to the vas deferens (VD) by means of a short vas efferens (VE). There is a single pair of tubular coiled (in situ) accessory glands (AG) which opens 
in the distal end of the ductus ejaculatorius (DE), and so can be regarded as ectadenia (Fig. 4). The diameter of the accessory glands in its basal fifth is almost twice as large as the remaining portion. The ductus ejaculatorius is short and very dilated specially in its basal portion. Similar characteristics were observed by Fenemore (1971) in males of $C$. zealandica and by Berberet \& Helms (1972) in $P$. anxia. Both the accessory glands and the vasa deferentia have a more translucent color in all.

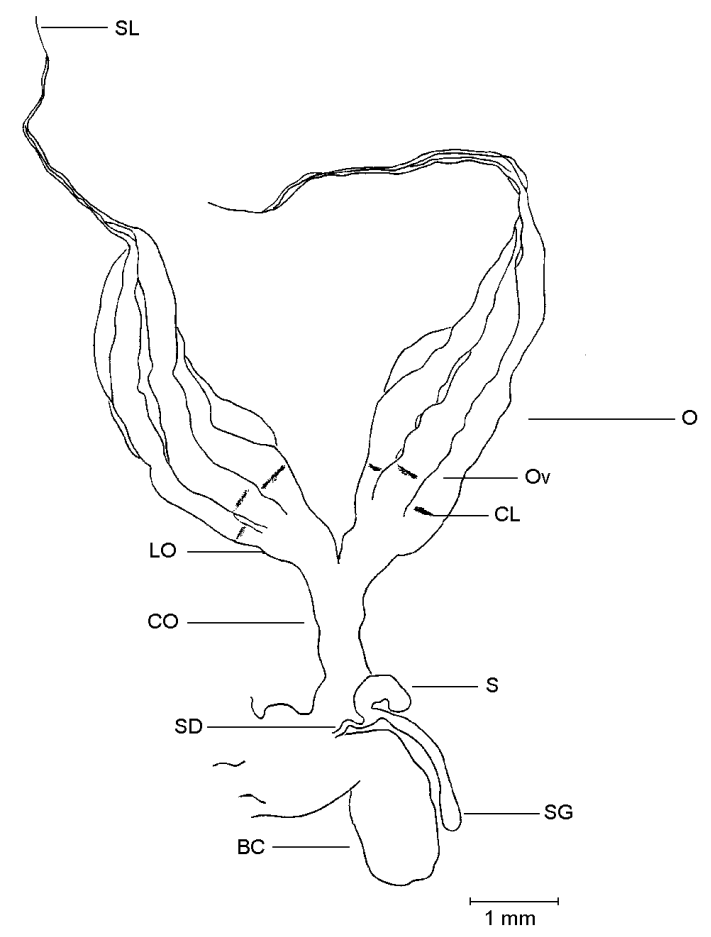

Fig. 3 - Female internal reproductive organs of a postreproductive specimen of Phytalus sanctipauli Blanchard, dorsal view. $\mathrm{BC}$ - bursa copulatrix; $\mathrm{CL}$ - corpora lutea; $\mathrm{CO}$ common oviduct; LO - lateral oviduct; O - ovary; Ov -ovariole; S spermatheca; SD spermathecal duct, SG - spermathecal gland; SL - suspensory ligament.

In the mature male the whole system is not conspicuously larger than in immature individuals (Figs. 4 and 5). The 6 testicular lobes of each testis are all individualized and usually smaller in size relative to the testicular lobes of immature males (Figs. 4 and 5). In average the diameter of the testicular lobe is $0.94 \pm 0.015 \mathrm{~mm}$ and 0.71 $\pm 0.021 \mathrm{~mm}$ respectively in immature and mature males $(\mathrm{t}=8.54 ; \mathrm{df}=178 ; \mathrm{P}<0.001)$. This reduction of the size of the testicular lobes could be explained by the transference of the sperm from the testis to the vasa deferentia. The latter becomes very enlarged in diameter. The accessory glands increase in diameter almost twice and become longer than in immatures. They show a milky white color in the basal region and a translucent appearance in its apex.

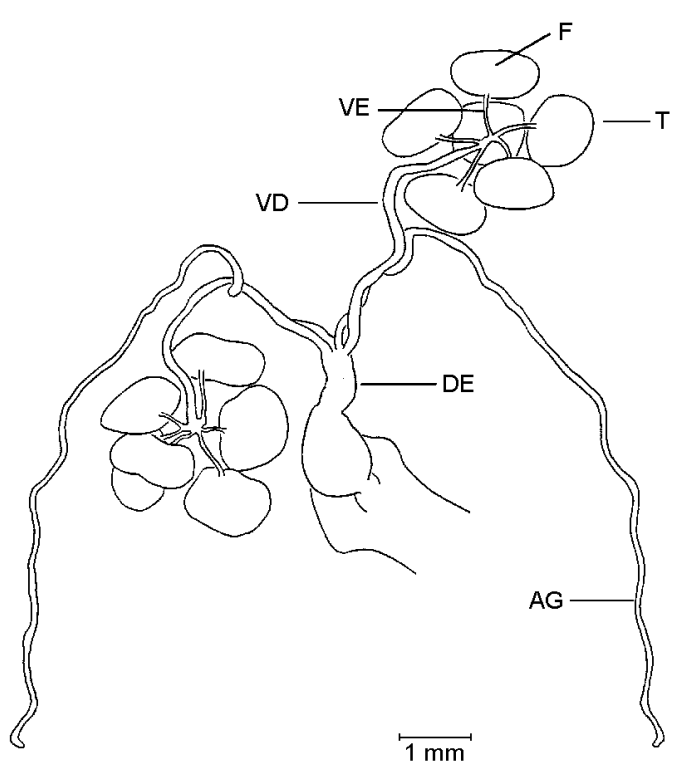

Fig. 4 - Male internal reproductive organs of a sexually immature specimen of Phytalus sanctipauli Blanchard, dorsal view. AG - accessory gland; DE - ductus ejaculatorius; F follicle; T - testis; VD - vas deferens; VE - vas eferens.

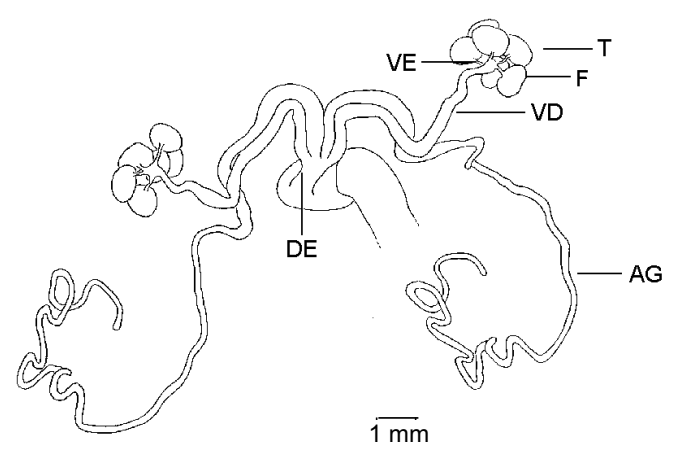

Fig. 5 - Male internal reproductive organs of a sexually mature specimen of Phytalus sanctipauli Blanchard, dorsal view. AG - accessory gland; DE - ductus ejaculatorius; F follicle; T - testis, VD - vas deferens; VE - vas eferens.

\section{Diapause characterization}

From the end of March until middle September the internal reproductive organs of all dissected male and female adults of $P$. sanctipauli were of the immature type, and the abdominal 
cavities were filled up by fat body. According to Lees (1955), Beck (1980) and Tauber et al. (1986), these conditions characterize the occurrence of imaginal diapause state. Therefore, it is valid to assume that $P$. sanctipauli presents imaginal reproductive diapause and stays in this condition for almost seven months. From middle September onwards a progressive maturation of the reproductive organs in both sexes was recorded. There are air sacs progressively inflated (Fig. 6) which fill up more and more abdominal space as the fat body dwindles and the reproductive organs mature. The air sacs are structures that help in the flight (Chapman, 1985), thus, its development may indicate that the time for soil emergence and swarming activity for mating is about to happens. This coupled with the sexual maturation points out to the end of the diapause period.

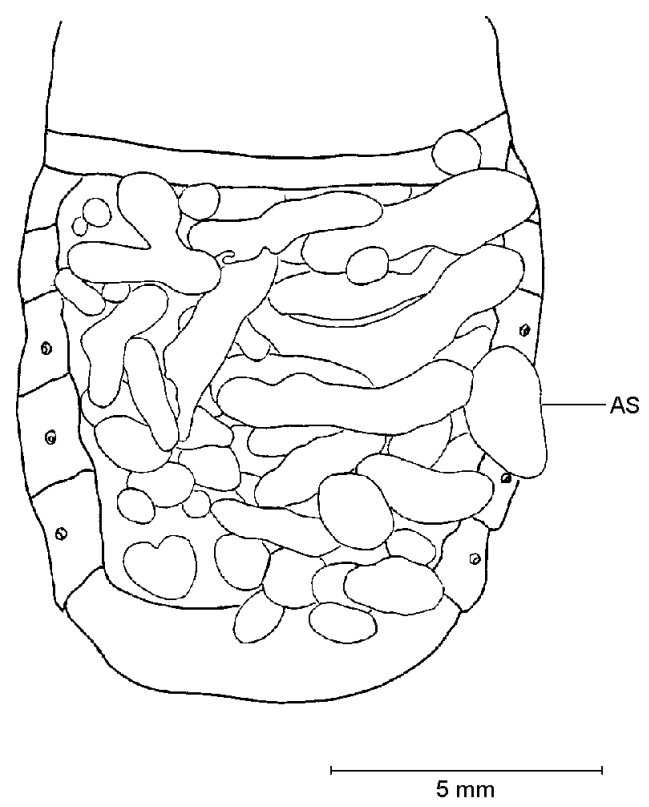

Fig. 6 - Dorsal view of the abdomen of Phytalus sanctipauli Blanchard collected from mid September onwards with integument partially removed. AS - air sacs (totally inflated).

Diapause in the present investigation was confirmed based upon systematic sampling, dissection and observation of the developmental stage of the reproductive organs in females and males from the end of summer until beginning of the spring. Although other authors like Sweetman (1931), Richter (1940), Guppy \& Harcourt (1970) and Berberet \& Helms (1972) had also referred to the presence of imaginal overwintering of various species of the genus Phyllophaga, only Berberet \& Helms (1972) based their statements on dissections and assessment of the maturation of the reproductive system as was herein done for P. sanctipauli.

The data here presented may help in the interpretation of the long staying of $P$. sanctipauli as adults in the soil. Also, they furnish a hint in an integrated pest management program, of a suitable period to take control steps, like microbial control, considering the insect lower activity, permanence in a sole local and the favorability of the soil as a medium for development of microorganisms.

Acknowledgements - Thanks are due to Mr. Iedo Santos and Ms. Nereide Almeida (CNPT-EMBRAPA) for their diligent assistance in field work; to MSc. Aline B. P. dos Santos, for aiding in the final drawing of the figures; to Dra. Helena P. Romanowski for reviewing the manuscript and to FAPERGS (Proc. 94/0716.0) for the financial aid. L M. G. Diefenbach is research fellow of the CNPq (proc. 300172/94-0).

\section{REFERENCES}

BARRATT, B. L. P. \& CAMPBELL, R. A., 1982, Biology of the striped chafer, Odontria striata (Coleoptera: Scarabaeidae) I. The adult, flight and ground surface activity, female reproductive maturation, and food-plant selection. N. Z. J. Zool., 9: 249-266.

BECK, S. D., 1980, Insect photoperiodism. 2nd ed. New York. Academic Press, 387p.

BERBERET, R. C. \& HELMS, T. J., 1972, Comparative anatomy and histology of selected systems in larval and adult Phyllophaga anxia (Coleoptera: Scarabaeidae). Ann. Entomol. Soc. Am. 65: 1026-1053.

CHAPMAN, R. F., 1985, The insects: structure and function. 3rd ed. Hong Kong, Hodder and Stoughton, 919p.

CROWSON, R. A., 1981, The biology of Coleoptera. London, Academic Press, 802p.

DIEFENBACH, L. M. G., REDAELLI, L. R., \&: GASSEN, D. N., 1996, Aspects of the population dynamics of Phytalus sanctipauli in Southern Brazil. In: T. A., Jackson, \& T. R., Glare (eds.). Microbial Control of Soil Dwelling Pests, 3. Lincoln, New Zealand, 21-23 February 1996. Proceedings, Lincoln, The Microbial Control Group, AgResearch, pp. 101-102.

FENEMORE, P. G., 1971, The internal condition of adult Costelytra zealandica (White) of known age and mated state. N. Z. J. Sc., 14: 77-88.

FUJIYAMA, S., 1983, The larval diapause of three scarabaeid beetles and its function in their life cycles. In: V. K. Brown \& I., Hodek, (eds). Diapause and life cycle strategies in insects, The Hague, DR. W. Junk Publishers, pp. 55-66. 
GASSEN, D. N., 1993, Corós associados ao sistema de plantio direto. In: Plantio Direto no Brasil, Passo Fundo, Editora Aldeia Norte, pp. 141-149.

GUPPY, J. C. \& HARCOURT, D. G., 1970, Spatial pattern of the immature stages and teneral adults of Phyllophaga spp. (Coleoptera: Scarabaeidae) in a permanent meadow. Can. Ent., 102:1354-1359.

LEES, A. D., 1955, The physiology of diapause in arthropods. London, Cambridge University Press, 151p.

MAELZER, D. A., 1961, The behaviour of the adult of Aphodius tasmaniae Hope (Col., Scarabaeidae) in South Australia. Bull. Ent. Res., 51: 643-670.

MERCER, C. F. \& KING, P. D., 1976, Ovarian development in black beetle, Heteronychus arator (Coleoptera: Scarabaeidae). N. Z. Entomol., 6: 165-170.
RICHTER, P. O., 1940, Kentucky white grubs. Kentucky Agr. Exp. Sta. Bull., 401: 71-157.

ROBERTSON, J. G., 1961, Ovariole numbers in Coleoptera. Can. J. Zool., 39: 245-263.

SWEETMAN, H. L., 1931, Preliminary report on the physical ecology of certain Phyllophaga (Scarabaeidae, Coleoptera). Ecology, 12: 401-422.

TAUBER, M. J., TAUBER, C. A. \& MASAKI, S., 1986, Seasonal adaptation of insects. New York, Oxford University Press, 411p.

WILLIAMS, J. L., 1945, The anatomy of the internal genitalia of some Coleoptera. Entomol. Soc. Wash, 47: 73-91. 